\title{
Mechanisms Employed by Trichoderma Species in the Biological Control of Plant Diseases: The History and Evolution of Current Concepts
}

Fungal species belonging to the genus Trichoderma are worldwide in occurrence and easily isolated from soil, decaying wood, and other forms of plant organic matter. They are, for the most part, classified as imperfect fungi, in that they have no known sexual stage. Rapid growth rate in culture and the production of numerous spores (conidia) that are varying shades of green characterize fungi in this genus. The reverse side of colonies is often uncolored, buff, yellow, amber, or yellow-green, and many species produce prodigious quantities of thick-walled spores (chlamydospores) in submerged mycelium (8). The potential of Trichoderma species as biocontrol agents of plant diseases was first recognized in the early 1930s (31), and in subsequent years, control of many diseases has been added to the list $(1,3,5,7,9,11,19$, $23,29,34,37,40)$. This has culminated in the commercial production of several Trichoderma species for the protection and growth enhancement of a number of crops in the United States (24), and in the production of Trichoderma species and mixtures of species in India, Israel, New Zealand, and Sweden (D. R. Fravel, personal communication).

One of the most interesting aspects of the science of biological control is the study of the mechanisms employed by biocontrol agents to effect disease control. Past research indicates that the mechanisms are many and varied, even within the genus Trichoderma. In order to make the most effective use of biocontrol agents for the control of plant diseases, we must understand how the agents work and what their limitations are. We can then develop effective means of culturing, storing, applying, and utilizing biocontrol agents so that we harness their best effort for disease

Dr. Howell's address is: USDA/ARS Southern Plains Agricultural Research Center, 2765 F\&B Road, College Station, TX 77845

E-mail: chowell@cpru.usda.gov

Publication no. D-2002-1028-01F

This article is in the public domain and not copyrightable. It may be freely reprinted with customary crediting of the source. The American Phytopathological Society, 2003. control. The selected research papers cited in this article were chosen because they illustrate what has been learned about mechanisms involved in biocontrol with Trichoderma species.

\section{Mycoparasitism and Antibiotic (Toxin) Production}

Those who are familiar with members of the genus Trichoderma know that one of the most salient characteristics of the group is their ability to parasitize other fungi (Fig. 1). It is therefore not surprising that Weindling (31) ascribed biocontrol by $T$. lignorum of citrus seedling disease, incited by Rhizoctonia solani, to mycoparasitism. Weindling described in detail the mycoparasitism of $R$. solani hyphae by the hyphae of the biocontrol agent, including coiling around pathogen hyphae, penetration, and subsequent dissolution of the host cytoplasm. This phenomenon occurred regardless of the supply of external nutrients to the host or mycoparasite. Although he considered the possibility that under certain circumstances $T$. lignorum might act as a competitor for nutrients with $R$. solani, he much favored mycoparasitism as the principal mechanism for biocontrol.

Two years later, Weindling (32) reported that a strain of $T$. lignorum produced a "lethal principle" that was excreted into the surrounding medium, allowing parasitic activity by the biocontrol agent. In 1941 (33), he characterized the "lethal principle", demonstrated that it was toxic to both $R$. solani and Sclerotinia americana, and named it gliotoxin (Fig. 2). Subsequently, it has been demonstrated that the fungus that produced gliotoxin was not $T$. lignorum, but Gliocladium virens (30), a species that has recently been renamed Trichoderma virens (27).

In the years following this seminal work, many instances of successful biocontrol with Trichoderma species have been ascribed to the mechanisms of mycoparasitism and/or antibiosis $(1,3,5,11,17,20,34)$.

The importance of antibiotics for biocontrol activity was demonstrated in sev-

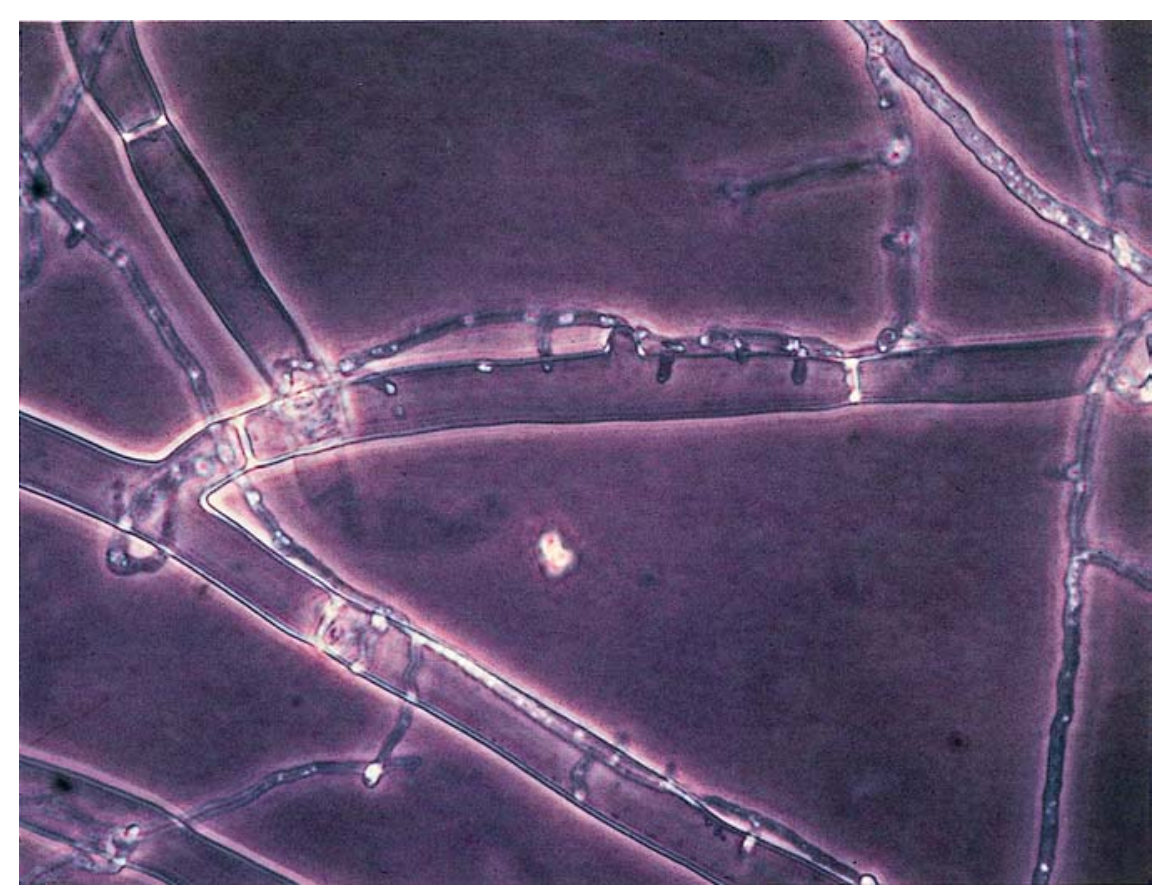

Fig. 1. Penetration and haustoria formation within the large hyphae of Rhizoctonia solani by the smaller hyphae of Trichoderma virens. 
eral studies. In 1983, Howell and Stipanovic (15) isolated and described a new antibiotic, gliovirin, from Gliocladium (Trichoderma) virens (GV-P) that was strongly inhibitory to Pythium ultimum and a Phytophthora species, but not to $R$. solani, Thielaviopsis basicola, Phymatotrichum omnivorum, Rhizopus arrhizus, or Verticillium dahliae. Gliovirin also was not inhibitory to the bacteria Bacillus thuringensis and Pseudomonas fluorescens. They demonstrated that mutants unable to synthesize the antibiotic lost the capacity to control Pythium damping-off of cotton. However, a mutant (GV-1) with enhanced gliovirin production was no more effective than the wild type in controlling the disease (Fig. 3). In another instance, Lifshitz et al. (19) showed that control of Pythium species on peas by $T$. harzianum (T-12) and T. koningii (T-8) was not due to either mycoparasitism or competition. They ascribed biocontrol to the production of a toxic factor by the biocontrol agent in the spermosphere that inhibited growth of the pathogen. Lumsden et al. (23) found that suppressive activity of $T$. virens (GL-21) to damping-off of zinnias, incited by both $R$. solani and $P$. ultimum, was correlated with production of the antibiotic gliotoxin by the biocontrol agent. Further, Wilhite et al. (35) used mutation to demonstrate that loss of gliotoxin production in $T$. virens mutants (G20-M36, M37, M50, and M96) had an adverse effect on the efficacy of these strains as biocontrol agents of Pythium damping-off. The difficulty of correlating loss of antibiotic biosynthesis with a decrease in biocontrol activity, using mutants generated by ultraviolet light, is that the roles of silent mutations in the process are not considered.

Other studies utilizing the techniques of genetic manipulation of microbes have brought some of the assumptions about the respective roles of mycoparasitism and antibiotic production in biological control into question. In 1987, Howell (12) used ultraviolet light irradiation to produce mu- tant strains of $T$. virens (G6-2, -15, and -57) that were unable to parasitize $R$. solani (Fig. 4). However, antibiotic biosynthesis did not differ from the parent strains. When compared for biocontrol efficacy against $R$. solani-incited cotton seedling disease, the mycoparasitic-deficient mutants were just as effective as the parent strains. These results indicated that mycoparasitism was not a major mechanism in the biocontrol of this particular disease.

Later studies also raised questions about the role of the antibiotic gliotoxin produced by $T$. virens as a mechanism in biocontrol of cotton seedling disease incited by $R$. solani. In one instance (16), mutants of $T$. virens that were deficient in gliotoxin biosynthesis were just as effective in controlling the disease as parent strains (Fig. $5)$. In other studies $(13,14)$, a mutant of $T$. virens deficient for both mycoparasitism and gliotoxin biosynthesis (G6-5) still retained biocontrol efficacy equal to that of the parent strain (G-6) against both $P$. ultimum and $R$. solani. These results indicate that neither mycoparasitism nor antibiosis is required for biocontrol of cotton seedling diseases incited by these pathogens.

\section{Competition and Rhizosphere Competence}

If mycoparasitism and antibiosis are not the principal mechanisms in the biocontrol process, what is? One mechanism that has gained adherents in recent years is that of competition through rhizosphere competence. Rhizosphere competence is important because a biocontrol agent cannot compete for space and nutrients if it is unable to grow in the rhizosphere. Trichoderma species, either added to the soil or applied as seed treatments, grow readily along with the developing root system of the treated plant $(9,14,40)$. This can be shown easily by simply plating surfacesterilized root segments from treated plants on an agar medium (Fig. 6). After a suitable incubation period, the fungus can be seen growing from virtually all parts of the

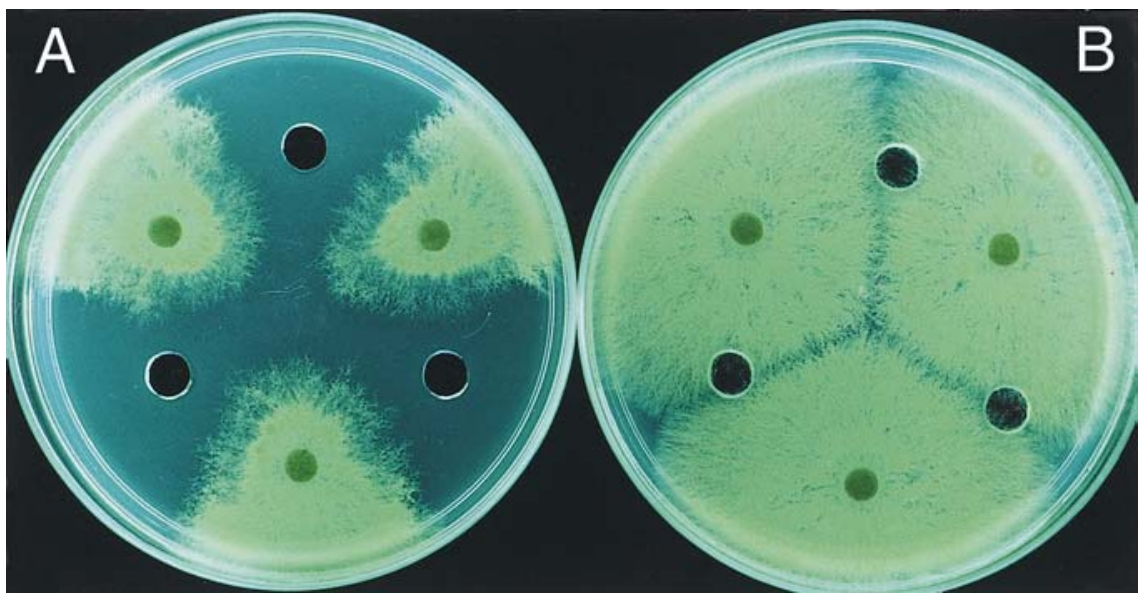

Fig. 2. Growth inhibition of Rhizoctonia solani by the Trichoderma virens-produced antibiotic gliotoxin: A, gliotoxin-amended medium, and B, nonamended medium. root. The difficulty in viewing competition through rhizosphere competence as a major mechanism in biological control is that strains of $T$. koningii that are excellent root colonizers exhibit little or no biocontrol activity against $R$. solani on cotton seedlings (C. R. Howell, unpublished). Although competition through rhizosphere competence may not be among the principal mechanisms that drive biological control, it is certainly a valuable adjunct to those that do. One concept that is associated with competition and rhizosphere competence, the replacement of endogenous fungi on the root surface (10), can be difficult to demonstrate. Trichoderma species are often able to suppress the growth of endogenous fungi on an agar medium and therefore mask their presence. A case in point is that of $T$. virens-treated root segments taken from soil heavily infested with propagules of Macrophomina phaseolina, the pathogen that causes charcoal rot in a wide range of crops. When these segments are plated on an agar medium at room temperature, only $T$. virens grows from the root. However, if these same cultures are incubated at $40^{\circ} \mathrm{C}$, a temperature at which $T$. virens will not grow, the pathogen grows readily from many parts of the root system (Fig. 7). This may also occur with other Trichoderma species and other pathogens, but it is not easily demonstrated because growth of the biocontrol agent can't be suppressed without suppressing the pathogen also. One method of demonstrating pathogen replacement on the roots by biocontrol agents might be through the use of fungicide-resistant strains of the pathogen and culture of infested roots on a medium amended with fungicide suppressive only to the biocontrol agent.

\section{Enzymes}

More recent research into the possible mechanisms involved in biological control by Trichoderma species has led to several

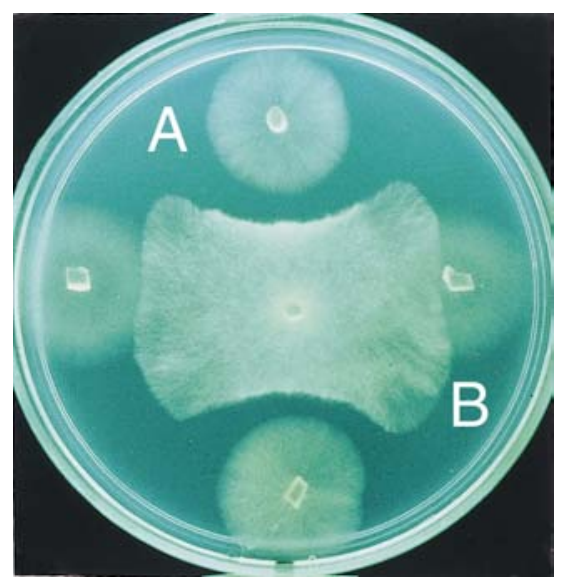

Fig. 3. Growth inhibition of Pythium ultimum by the Trichoderma virensproduced antibiotic gliovirin: $A$, parent strain, and B, gliovirin-deficient mutant. 
alternative explanations for successful biocontrol. One idea that has been advanced is that enzymes such as chitinases and/or glucanases produced by the biocontrol agent are responsible for suppression
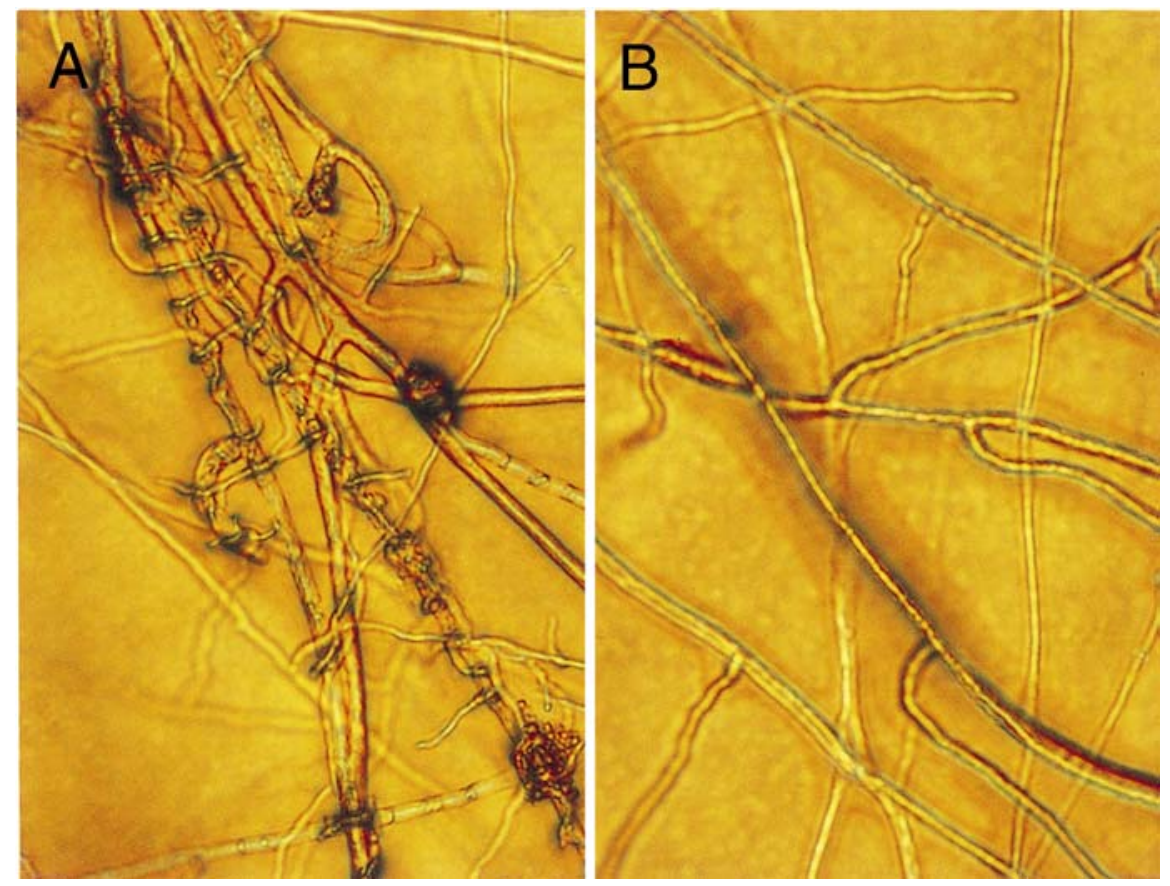

Fig. 4. Mycoparasitism of Rhizoctonia solani by Trichoderma virens: A, parent strain coiling around host hyphae, and B, mycoparasitic-deficient mutant with no coiling or penetration of host hyphae.

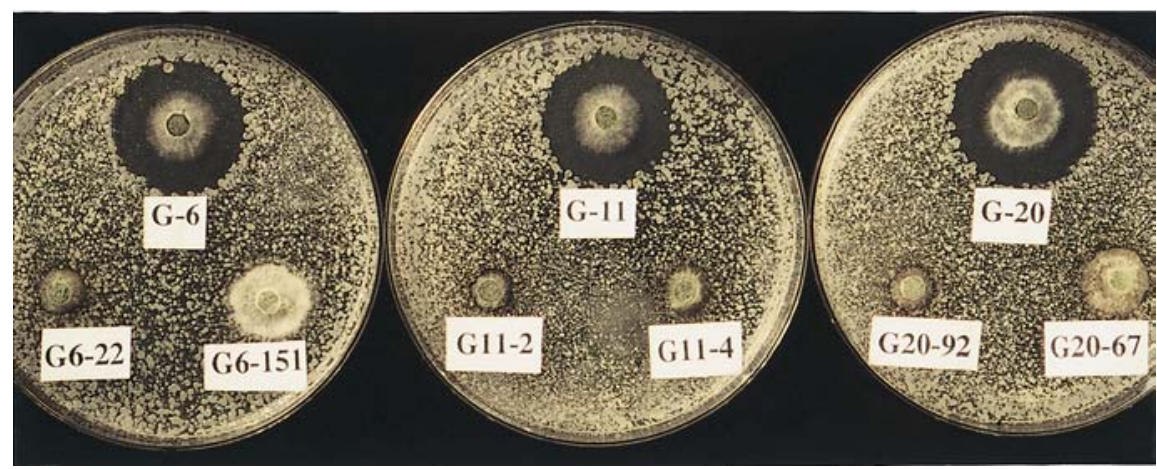

Fig. 5. Trichoderma virens strains cultured on potato dextrose agar amended with a Bacillus subtilis lawn. G-6, G-11, and G-20 are parent strains. G6-22 and -151, G11-2 and -4 , and $G 20-92$ and -67 are gliotoxin-deficient mutants.

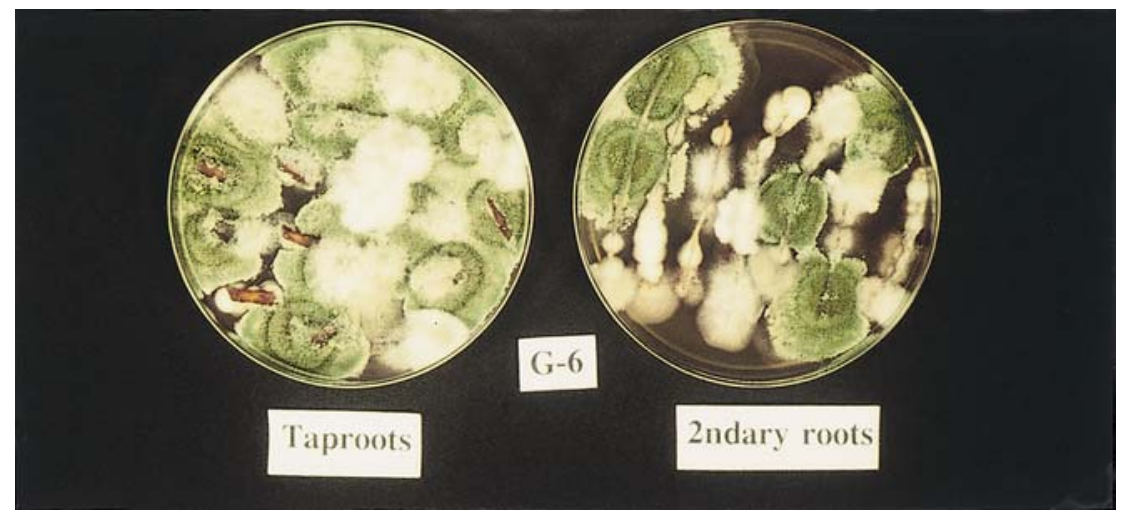

Fig. 6. Trichoderma virens cultured from tap and secondary roots of cotton plants grown from $T$. virens-coated seed in field soil.
Metcalf and Wilson (25) described the colonization of onion roots, infected with Sclerotium cepivorum, by T. koningii $(\operatorname{Tr} 5)$. Hyphae of the biocontrol agent penetrated into infected epidermal and cortical tissue of the root to destroy the hyphae of the pathogen, with little or no damage to uninfected plant tissue. The authors ascribed this biocontrol phenomenon to production of endo- and exo-chitinases by T. koningii. Baek et al. (2) disrupted or over-expressed the gene coding for chitinase (cht42) in $T$. virens (Gv29-8). Transformants with reduced enzyme activity or over-expression of the enzyme gave significantly decreased or enhanced biocontrol activity, respectively, against $R$. solani-incited cotton seedling disease. However, the differences were not great and probably indicate that other factors were also at work. In a similar study, Woo et al. (36) also disrupted chitinase (ech42) activity in T. harzianum (P1) and showed reduced biocontrol activity against Botrytis cinerea on bean leaves. However, the transformant was as effective as the wild type against $P$. ultimum and exhibited enhanced activity against $R$. solani when compared with the control. The authors concluded that reactions between $T$. harzianum strains and various fungal hosts were based on different mechanisms. This, again, indicates that factors other than chitinase activity are important to the biocontrol process. The possible role of chitinolytic enzymes in biocontrol is further supported by the work of Lorito et al. (22), who transferred the gene encoding endochitinase from $T$. harzianum (P1) into tobacco and potato and demonstrated a high level and broad spectrum of resistance against a number of plant pathogens. Recently, Bolar et al. (4) demonstrated enhanced resistance to apple scab incited by Venturia inaequalis in transgenic apple plants that had been transformed with genes encoding both endoand exo-chitinases from $T$. atroviride (P1). Finally (C. M. Kenerley, personal communication), a gene from T. virens (Gv29-8) encoding a 42-kDa endochitinase under control of the CaMV 35S promoter was transformed into the cotton cultivar Coker 312. Transgenic lines were screened for fungal chitinase activity, and several high producers were identified. Homozygous lines were generated that retained high enzyme activity and expression of this gene in the roots, shoots, and leaves. Seedlings of these lines were screened against the seedling pathogens Rhizoctonia solani and Thielaviopsis basicola, and detached leaves were screened against Alternaria alternata. Selected transgenic lines demonstrated significant levels of resistance against all three pathogens when compared with the parental control and a commercial cotton cultivar.

Another interesting concept related to enzyme biosynthesis as a mechanism in the biocontrol process is that advanced by Elad 
and Kapat (7) and Kapat et al. (18), who suggested that biocontrol of $B$. cinerea by T. harzianum (T39) might be due, in part, to the actions of $T$. harzianum-produced proteases that inactivate the hydrolytic enzymes produced by $B$. cinerea on bean leaves. The protease enzymes break down hydrolytic enzymes into peptide chains and/or their constituent amino acids and thereby destroy their capacity to act on plant cells. The authors demonstrated that protease solutions produced by the biocontrol fungus on bean leaves partially deactivated hydrolytic enzymes and reduced disease severity by 56 to $100 \%$ when the solutions were used to treat leaves infected with the pathogen. They also showed that the addition of protease inhibitors to drops containing mixed conidia of the two fungi, applied to bean leaves, nullified the biocontrol effect of the T. harzianum conidia.

Protease production by $T$. harzianum has also been associated with biocontrol of the root-knot nematode Meloidogyne javanica on tomato plants. Sharon et al. (29) showed that tomato plants treated with the biocontrol agent (T-203) and grown in nematodeinfested soil exhibited a drastic reduction in root galling when compared with the control. A transformed strain of $T$. harzianum (P2) containing multiple copies of a gene-encoding protease reduced root galling better than wild-type strains, and it was the only strain able to penetrate egg masses and the eggs inside. The authors suggested that improved proteolytic activity might be important for biological control of nematodes.

Finally, Migheli et al. (26) showed that transformants of $T$. longibrachiatum (CECT2606), over-expressing a gene encoding $\beta$-1,4-endoglucanase, were slightly more effective in the biocontrol of $P$. ultimum on cucumber than the wild type. They concluded that a mixture of several enzymes might be necessary for efficient cell wall lysis.

The concept of enzyme biosynthesis as a mechanism of biocontrol has been expanded to include synergism between enzymes and antibiotics. Di Pietro et al. (6) studied the synergistic effects of endochitinase and gliotoxin on conidial germination of $B$. cinerea. They found that treatment of $B$. cinerea conidia with the combination was much more effective than treatment with the enzyme or antibiotic alone. Schirmbock et al. (28) noticed a similar effect on conidial germination and hyphal elongation of $B$. cinerea when the fungus was treated with combinations of hydrolytic enzymes and peptaibols produced by T. harzianum (ATCC 36042). Neither the enzymes nor the antibiotics alone were as effective as a combination of the two. Lorito et al. (21) further expanded this concept by combining a number of antifungal compounds with several kinds of hydrolytic enzymes and applying them to propagules of $B$. cinerea and Fusarium oxysporum. Synergism occurred in all cases, but the level depended on the antifungal activity of the enzyme. Synergism was lower when the enzyme was added after the antifungal compound, indicating that cell wall degradation was needed in order to establish the interaction.

\section{Induction of Defense Responses in Plants}

Another mechanism proposed to explain biocontrol activity by Trichoderma species is that of induction of resistance in the host plant by treatment with the biocontrol agent. This concept is supported by the work of Yedidia et al. (37), who demonstrated that inoculating roots of 7-day-old cucumber seedlings in an aseptic hydroponic system with $T$. harzianum (T-203) spores to a final concentration of $10^{5}$ per $\mathrm{ml}$ initiated plant defense responses in both the roots and leaves of treated plants. They also demonstrated that hyphae of the biocontrol fungus penetrated the epidermis and upper cortex of the cucumber root. The plant response was marked by an increase in peroxidase activity (often associated with the production of fungitoxic compounds), an increase in chitinase activity, and the deposition of callose-enriched wall appositions on the inner surface of cell walls. Increased enzyme activities were observed in both roots and leaves. Interestingly, the plant defense became muted with time and began to resemble a symbiotic mycorrhizal association. Later, Yedidia et al. (38) showed that inoculation of cucumber roots with $T$. harzianum (T-203) induced an array of pathogenesis-related proteins, including a number of hydrolytic enzymes. Plants treated with a chemical inducer (2,6-dichloroisonicotinic acid) of disease resistance displayed defense responses that were similar to those of plants inoculated with the biocontrol agent.

In another study, Howell et al. (14) demonstrated that seed treatment of cotton with biocontrol preparations of T. virens (G-6, G-11, G6-5) or application of $T$. virens culture filtrate to cotton seedling radicles induced synthesis of much higher concentrations of the terpenoids desoxyhemigossypol (dHG), hemigossypol (HG), and gossypol (G) in developing roots than those found in untreated controls. Gossypol was toxic only at high levels, but the pathway intermediates $\mathrm{dHG}$ and $\mathrm{HG}$ were strongly inhibitory to the cotton seedling pathogen, $R$. solani, at much lower concentrations. Trichoderma species were much more resistant to cotton terpenoids than were seedling disease pathogens. Biocontrol activity against $R$. solani was highly correlated with induction of terpenoid synthesis in cotton roots by Trichoderma species, even among strains of $T$. virens that were deficient for mycoparasitism and antibiotic production. In addition to terpenoid synthesis, treatment of cotton roots with $T$. virens also induced significantly higher levels of peroxidase activity than that found in control roots. Peroxidase activity and terpenoid levels in seedling hypocotyls were not significantly different from those found in the controls. In this case, plant defense responses appeared to be confined to the root system.

\section{Metabolism of Germination Stimulants}

One unique mechanism employed by Trichoderma species to effect biological control that does not fit neatly into any of the categories previously mentioned was recently discovered. In a study of the mechanisms involved in the biocontrol of preemergence damping-off of cotton seedlings incited by P. ultimum and/or Rhizopus oryzae, Howell (13) found that control by T. virens (G6, G6-5) or protoplast fusants of $T$. virens/T. longibrachiatum (Tvl-30, Tvl-35) was due to metabolism of germination stimulants released by the cotton seed. These compounds normally induced pathogen propagules to germinate. Disease control could be effected by wild-type strains or by mutant strains that were deficient for mycoparasitism, antibiotic production, and induction of terpenoid synthesis in cotton roots. If, however, pathogen

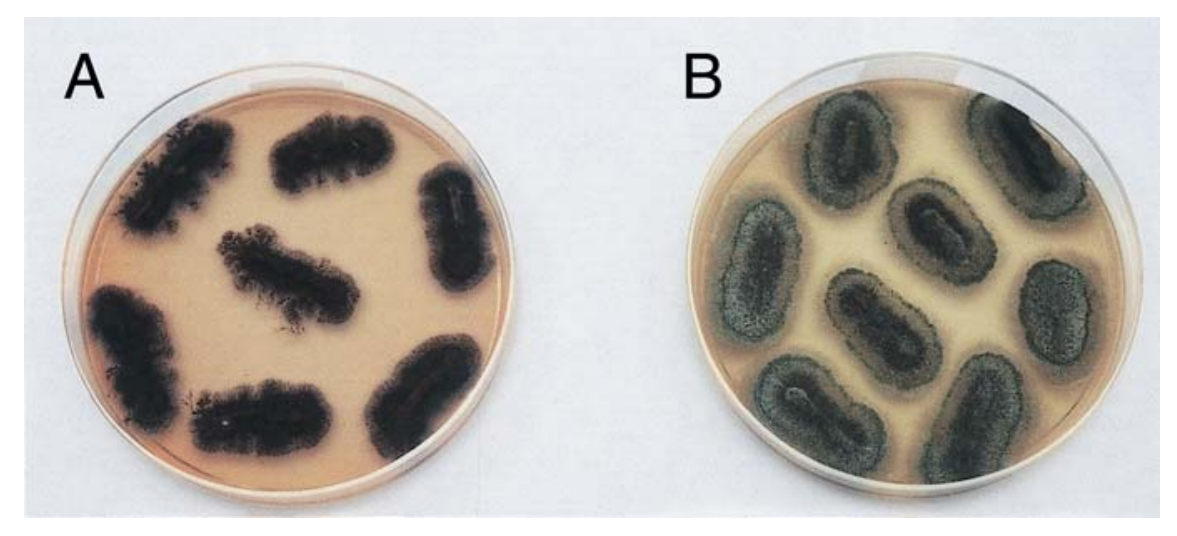

Fig. 7. Cultures of cotton roots from plants grown in Macrophomina phaseolinainfested soil and incubated at $25^{\circ} \mathrm{C}$ : A, roots from nontreated seed showing $M$. phaseolina, and $\mathrm{B}$, roots from Trichoderma virens-treated seed showing only the biocontrol agent. Incubation of $\mathrm{B}$ at $40^{\circ} \mathrm{C}$ shows only $\mathrm{M}$. phaseolina growing from cotton roots. 


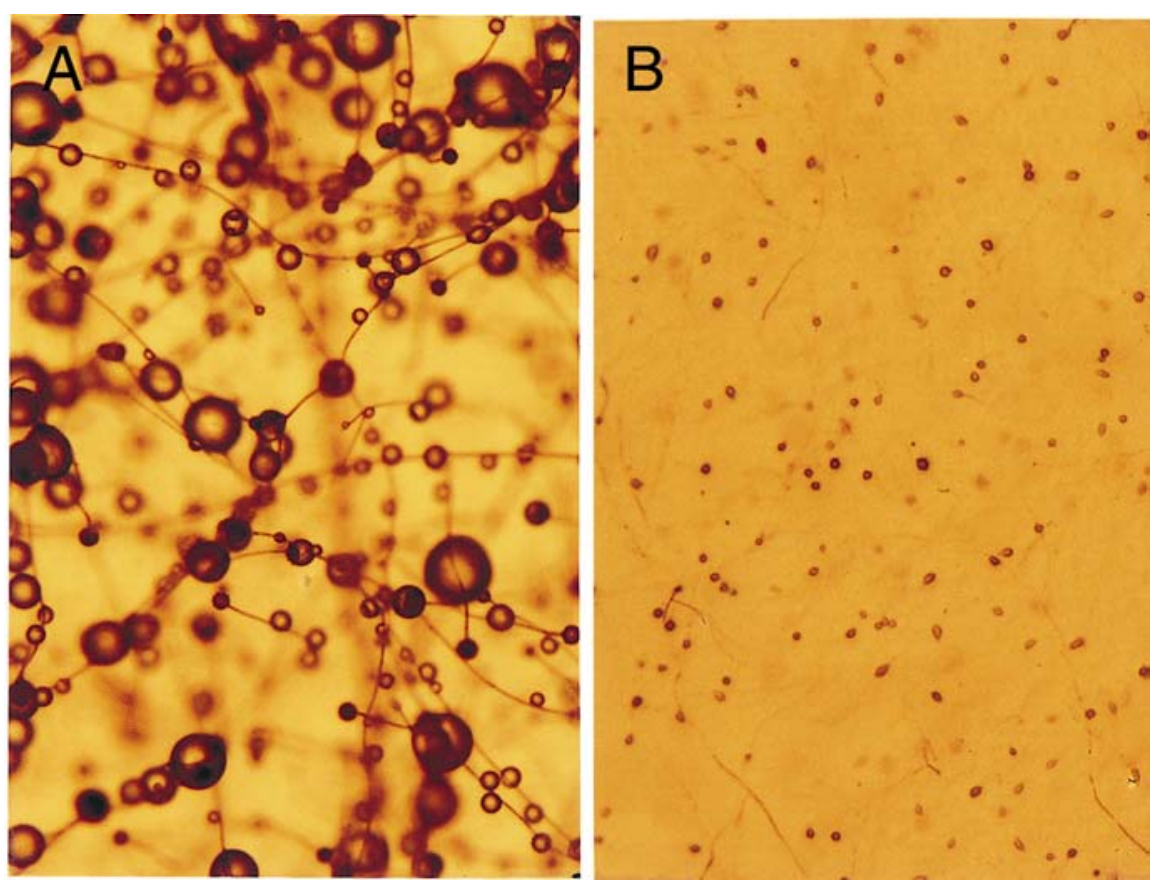

Fig. 8. Effect of seed exudates cultured with Trichoderma virens preparations on germination of Rhizopus oryzae sporangiospores: A, exudate cultured with dead $T$. virens preparation stimulates spore germination and mycelial growth of $\boldsymbol{R}$. oryzae, while B, exudate cultured with live $T$. virens preparation does not stimulate spore germination.

propagules were induced to germinate by artificial means, none of the above treatments gave effective control of the disease.

The importance of metabolism of stimulatory compounds by the biocontrol agent is further supported by the fact that cotton cultivars that do not produce pathogen propagule stimulants during germination are virtually immune to the disease. Again, artificial induction of pathogen propagule germination rendered these cotton cultivars susceptible to disease. Also, seed exudates cultured with dead $T$. virens biocontrol preparation stimulated pathogen propagules to germinate, while exudates cultured with live biocontrol preparation did not (Fig. 8).

\section{Adjunct Mechanisms}

While perhaps not of primary importance as mechanisms in biological control, Trichoderma species exhibit other characteristics during interactions with host plants that may contribute to disease resistance or tolerance. These characteristics manifest themselves by increases in plant root and shoot growth, resistance to biotic and abiotic stresses, and changes in the nutritional status of the plant. These phenomena have been thoroughly reviewed by Harman (9), who showed that seed treatment of corn planted in low nitrogen soil with $T$. harzianum (T-22) resulted in plants that were greener and larger in the early part of the growing season. At maturity, the treated plants had larger stem diameters and increased yields of grain and silage. In fields where nitrogen levels were suffi- cient, treatment with T-22 did not result in increased yields of grain or silage. However, the nitrogen required for optimum yields was lower for T-22 treated plants than for the untreated controls. Harman (10) later reported a strong interaction between T-22 and the nitrogen-fixing bacterium Bradyrhizobium japonicum. Treatment of soybeans with the combination stimulated root growth more effectively than did either alone. Theoretically, the combination of a nitrogen-fixing bacterium and a fungus that enables the plant to utilize nitrogen more efficiently should decrease even further the nitrogen fertilizer requirements of the crop. More recently, Yedidia et al. (39) showed that treatment of cucumber plants in soil with $T$. harzianum area and cumulative root length, and significant increases in dry weight, shoot length, and leaf area over that of the untreated control. In hydroponic culture, T203 inoculated cucumber roots contained significant increases in $\mathrm{Cu}, \mathrm{P}, \mathrm{Fe}, \mathrm{Zn}, \mathrm{Mn}$, and $\mathrm{Na}$. In the shoots of these plants, the concentrations of $\mathrm{Zn}, \mathrm{P}$, and $\mathrm{Mn}$ were increased. The authors considered that improvement of plant nutrition was directly related to the general beneficial growth effect on the root system of inoculation with $T$. harzianum

\section{Conclusions}

One of the things we have learned through research on biocontrol mechanisms employed by Trichoderma species is that the screening methods developed early (T-203) resulted in large increases in root on to isolate potential biocontrol agents were, at best, only marginally effective. Many strains were isolated because they were observed parasitizing plant pathogens or inhibiting their growth in culture. The enzymes and antibiotics produced by Trichoderma species that appear to be involved in biocontrol are strongly influenced by the substrate on which the fungus is grown, and conditions in the laboratory probably occur only rarely in nature or not at all. Temperature also has a profound effect on the production and activities of enzymes and antibiotics associated with biocontrol by Trichoderma species. What occurs at $78^{\circ} \mathrm{F}$ in a petri dish may not occur at all in the soil around a germinating seed at $60^{\circ} \mathrm{F}$. The presence of other members of the soil microflora also may influence biocontrol activity by inhibiting the growth and development of the biocontrol agent or by metabolizing its enzymatic and/or antibiotic products. This may not entirely negate the biocontrol activities of Trichoderma species, but it might well limit their efficacy in terms of the length of time that they are effective and the distance from the biocontrol focal point that they exhibit influence.

Given the above considerations, perhaps the best method for obtaining a potential biocontrol agent might be one where the candidate Trichoderma species is isolated from areas of the plant and soil where it is expected to function in disease control, and where it is growing under conditions of temperature, moisture, and nutrient availability that approximate those found in nature. Isolates obtained in this manner can then be screened for biocontrol efficacy. Since many of the mechanisms that have proven to be most important in biological control do not lend themselves to assay in a petri dish, the screening procedure will probably entail treatment of the seed, soil, or plant with the biocontrol agent. This can be followed by culture of the treated host plant in a pathogen-infested environment until disease symptoms manifest themselves. The level of symptom expression can be used as a measure of the disease control efficacy of the biocontrol agent.

The results of many years of research with Trichoderma species as biocontrol agents has shown that not all the mechanisms and characteristics deemed necessary for optimum biocontrol are found in the same organism. Very often those strains that have the capacity to produce enzymes and antibiotics that are associated with biocontrol are not the ones that have good storage qualities or function well at temperature and moisture levels where pathogens flourish. Therefore, hybridization of different strains or species will be required in order to combine these beneficial characteristics. The production of hybrids from Trichoderma species, many of which have no known sexual stage, will entail the use of transformation or protoplast fusion in 


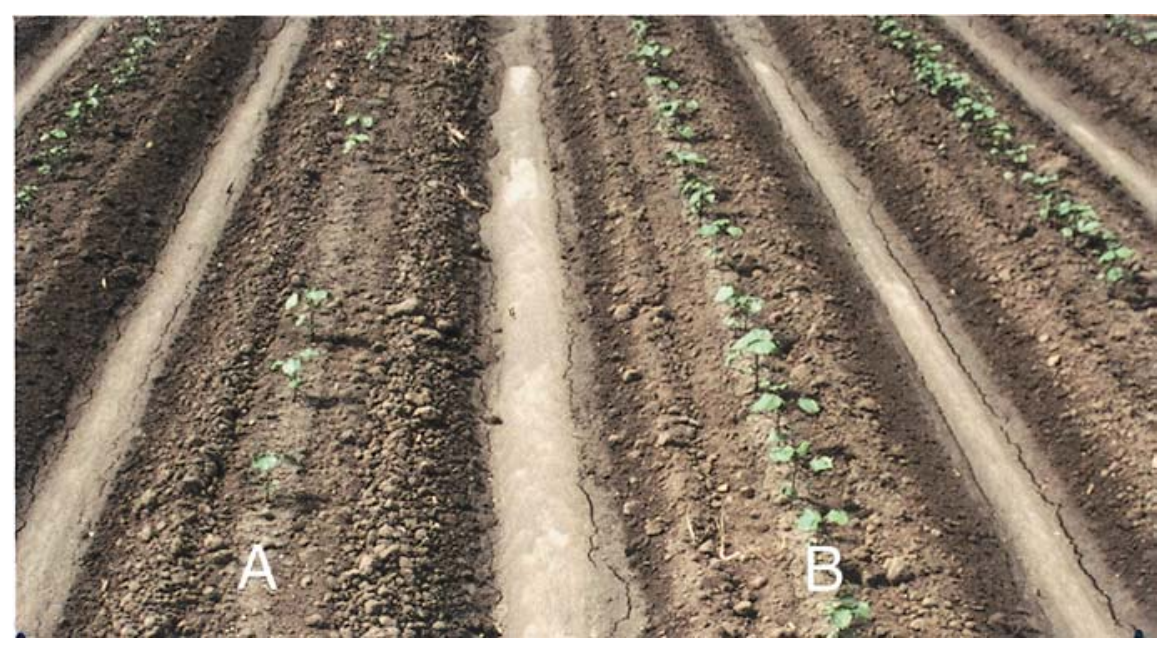

Fig. 9. Cotton seedling disease control field trial: A, preemergence damping-off skips occur in the row planted with untreated seed, while B, seed treatment with Trichoderma virens results in a complete and even stand. Photograph courtesy R. H. Garber, Shafter, CA.

order to obtain strains with optimal sets of characteristics. Once produced and screened, hybrids may yield strains with expanded host, temperature, and moisture parameters, and they may yield strains with better storage qualities than those exhibited by the parents.

The mechanisms employed by biocontrol agents to effect biological control of plant diseases are many and complex, and their use varies with the kind of biocontrol agent, pathogen, and host plant involved in the interaction. Mechanisms are also influenced by the soil type, by the temperature, $\mathrm{pH}$, and moisture of the plant and soil environment, and by other members of the microflora. What we observe and define as biocontrol may be the culmination of a number of different mechanisms working synergistically to achieve disease control. Our knowledge of the complexity of these systems is currently limited by our ability to perceive them, and a great deal of research will have to be undertaken in order to fathom exactly what is taking place during the biocontrol process. As with so many other aspects of science, basic knowledge about the mechanisms involved in the biocontrol process will be of immense value to those intent on developing new methods for utilizing biocontrol agents (Fig. 9).

\section{Literature Cited}

1. Aluko, M. O., and Hering, T. F. 1970. The mechanism associated with the antagonistic relationship between Corticium solani and Gliocladium virens. Trans. Br. Mycol. Soc. 55:173-179.

2. Baek, J. M., Howell, C. R., and Kenerley, C. M. 1999. The role of extracellular chitinase from Trichoderma virens Gv29-8 in the biocontrol of Rhizoctonia solani. Curr. Genet. 35:41-50.

3. Bliss, D. E. 1951. The destruction of Armillaria mellea in citrus soils. Phytopathology 41:665-683.

4. Bolar, J. P., Norelli, J. L., Wong, K.-W.,
Hayes, C. K., Harman, G. E., and Aldwinckle, H. S. 2000. Expression of endochitinase from Trichoderma harzianum in transgenic apple increases resistance to apple scab and reduces vigor. Phytopathology 90:72-77.

5. Chet, I. 1987. Trichoderma-Application, mode of action, and potential as a biocontrol agent of soilborne pathogenic fungi. Pages 137-160 in: Innovative Approaches to Plant Disease Control. I. Chet, ed. John Wiley \& Sons, New York.

6. Di Pietro, A., Lorito, M., Hayes, C. K., Broadway, R. M., and Harman, G. E. 1993. Endochitinase from Gliocladium virens: Isolation, characterization, and synergistic antifungal activity in combination with gliotoxin. Phytopathology 83:308-313.

7. Elad, Y., and Kapat, A. 1999. The role of Trichoderma harzianum protease in the biocontrol of Botrytis cinerea. Eur. J. Plant Pathol. 105:177-189.

8. Gams, W., and Bisset, J. 1998. Morphology and identification of Trichoderma. Pages 3-34 in: Trichoderma \& Gliocladium. Vol. 1. G. E. Harman and C. P. Kubicek, eds. Taylor and Francis, London.

9. Harman, G. E. 2000. Myths and dogmas of biocontrol: Changes in perceptions derived from research on Trichoderma harzianum T22. Plant Dis. 84:377-393.

10. Harman, G. E. 2001. Microbial tools to improve crop performance and profitability and to control plant diseases. Pages 4-1-4-14 in: Int. Sympos. Biol. Control Plant Dis. New Century-Mode Action Application Technol.

11. Howell, C. R. 1982. Effect of Gliocladium virens on Pythium ultimum, Rhizoctonia solani, and damping-off of cotton seedlings. Phytopathology 72:496-498.

12. Howell, C. R. 1987. Relevance of mycoparasitism in the biological control of Rhizoctonia solani by Gliocladium virens. Phytopathology 77:992-994.

13. Howell, C. R 2002. Cotton seedling preemergence damping-off incited by Rhizopus oryzae and Pythium spp. and its biological control with Trichoderma spp. Phytopathology 92:177-180.

14. Howell, C. R., Hanson, L. E., Stipanovic, R. D., and Puckhaber, L. S. 2000. Induction of terpenoid synthesis in cotton roots and control of Rhizoctonia solani by seed treatment with Trichoderma virens. Phytopathology 90:248252.

15. Howell, C. R., and Stipanovic, R. D. 1983.

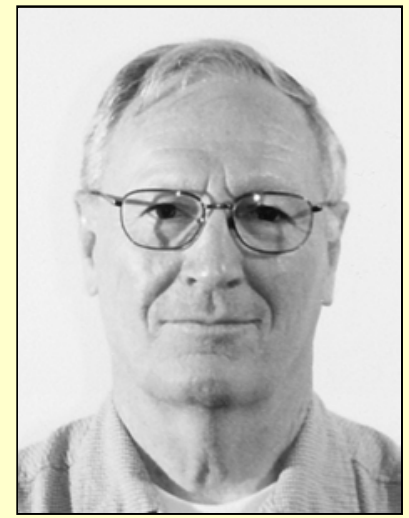

C. R. Howell

Dr. Howell is a research plant pathologist with the USDA/ARS at the Southern Plains Agricultural Research Center in College Station, TX. He received his B.S. in biological sciences from California State Polytechnic University in 1962, and a Ph.D. in plant pathology from Washington State University in 1967 . He then accepted a position with the USDA/ARS at the Texas A\&M Experiment Station in Lubbock, where he worked on Verticillium wilt of cotton. In 1970, he transferred to the Cotton Pathology Research Unit in College Station. He continued work on cotton wilts for 8 years; then he began a research program on the biological control of cotton seedling diseases with bacteria and fungi. His work has been concerned with the mechanisms employed by bacteria and fungi to effect seedling disease control, and with the effect of environment on the activities of biocontrol agents. His current research is focused on discovering the mechanisms in Trichoderma species that are associated with cotton seedling disease control, and on transferring beneficial traits from different sources into selected strains to optimize biocontrol efficacy.

Gliovirin, a new antibiotic from Gliocladium virens, and its role in the biological control of Pythium ultimum. Can. J. Microbiol. 29:321324.

16. Howell, C. R., and Stipanovic, R. D. 1995. Mechanisms in the biocontrol of Rhizoctonia solani-induced cotton seedling disease by Gliocladium virens: Antibiosis. Phytopathology 85:469-472.

17. Howell, C. R., Stipanovic, R. D., and Lumsden, R. D. 1993. Antibiotic production by strains of Gliocladium virens and its relation to the biocontrol of cotton seedling diseases. Biocontrol Sci. Technol. 3:435-441.

18. Kapat, A., Zimand, G., and Elad, Y. 1998 Effect of two isolates of Trichoderma harzianum on the activity of hydrolytic enzymes produced by Botrytis cinerea. Physiol. Mol. 
Plant Pathol. 52:127-137.

19. Lifshitz, R., Windham, M. T., and Baker, R. 1986. Mechanism of biological control of preemergence damping-off of pea by seed treatment with Trichoderma spp. Phytopathology 76:720-725.

20. Lo, C.-T., Nelson, E. B., Hayes, C. K., and Harman, G. E. 1998. Ecological studies of transformed Trichoderma harzianum strain 1295-22 in the rhizosphere and on the phylloplane of creeping bentgrass. Phytopathology $88: 129-136$

21. Lorito, M., Woo, S. L., D'Ambrosio, M., Harman, G. E., Hayes, C. K., Kubicek, C. P., and Scala, F. 1996. Synergistic interaction between cell wall degrading enzymes and membrane affecting compounds. Mol. Plant-Microbe Interact. 9:206-213.

22. Lorito, M., Woo, S. L., Fernandez, I. G., Collucci, G., Harman, G. E., Pintor-Toros, J. A., Filippone, E., Muccifora, S., Lawrence, C. B., Zoina, A., Tuzun, S., and Scala, F. 1998. Genes from mycoparasitic fungi as a source for improving plant resistance to fungal pathogens. Proc. Natl. Acad. Sci. USA 95:78607865.

23. Lumsden, R. D., Locke, J. C., Adkins, S. T., Walter, J. F., and Ridout, C. J. 1992. Isolation and localization of the antibiotic gliotoxin produced by Gliocladium virens from alginate prill in soil and soilless media. Phytopathology 82:230-235.

24. McSpadden Gardener, B. B., and Fravel, D. R. 2002. Biological control of plant pathogens: Research, commercialization, and application in the USA. Plant Health Progress. Online, publication doi:10.1094/PHP-20020510-01-RV.

25. Metcalf, D. D., and Wilson, C. R. 2001. The process of antagonism of Sclerotium cepi- vorum in white rot affected onion roots by Trichoderma koningii. Plant Pathol. 50:249257.

26. Migheli, Q., Gonzalez-Candelas, L., Dealessi, L., Camponogara, A., and Ramon-Vidal, D. 1998. Transformants of Trichoderma longibrachiatum overexpressing the $\beta$-1,4-endoglucanase gene egll show enhanced biocontrol of Pythium ultimum on cucumber. Phytopathology 88:673-677.

27. Rehner, S. A., and Samuels, G. J. 1994. Taxonomy and phylogeny of Gliocladium analyzed by large subunit ribosomal DNA sequences. Mycol. Res. 98:625-634.

28. Schirmbock, M., Lorito, M., Wang, Y. L., Hayes, C. K., Arisan-Atac, I., Scala, F., Harman, G. E., and Kubicek, C. P. 1994. Parallel formation and synergism of hydrolytic enzymes and peptaibol antibiotics, molecular mechanisms involved in the antagonistic action of Trichoderma harzianum against phytopathogenic fungi. Appl. Environ. Microbiol. 60:4364-4370.

29. Sharon, E., Bar-Eyal, M., Chet, I., HerraEstrella, A., Kleifeld, O., and Spiegel, Y. 2001. Biological control of the root-knot nematode Meloidogyne javanica by Trichoderma harzianum. Phytopathology 91:687693.

30. Webster, J., and Lomas, N. 1964. Does Trichoderma viride produce gliotoxin and viridin? Trans. Br. Mycol. Soc. 47:535-540.

31. Weindling, R. 1932. Trichoderma lignorum as a parasite of other soil fungi. Phytopathology 22:837-845.

32. Weindling, R. 1934. Studies on a lethal principle effective in the parasitic action of Trichoderma lignorum on Rhizoctonia solani and other soil fungi. Phytopathology 24:11531179.
33. Weindling, R. 1941. Experimental consideration of the mold toxin of Gliocladium and Trichoderma. Phytopathology 31:991-1003.

34. Wells, H. D., Bell, D. K., and Jaworski, C. A 1972. Efficacy of Trichoderma harzianum as a biocontrol for Sclerotium rolfsii. Phytopathology 62:442-447.

35. Wilhite, S. E., Lumsden, R. D., and Straney, D. C. 1994. Mutational analysis of gliotoxin production by the biocontrol fungus Gliocladium virens in relation to suppression of $\mathrm{Py}$ thium damping-off. Phytopathology 84:816821.

36. Woo, S. L., Donzelli, B., Scala, F., Mach, R., Harman, G. E., Kubicek, C. P., Del Sorbo, G., and Lorito, M. 1999. Disruption of the ech42 (endochitinase-encoding) gene affects biocontrol activity in Trichoderma harzianum $\mathrm{P} 1$. Mol. Plant-Microbe Interact. 12:419-429.

37. Yedidia, I., Benhamou, N., and Chet, I. 1999. Induction of defense responses in cucumber plants (Cucumis sativus L.) by the biocontrol agent Trichoderma harzianum. Appl. Environ. Microbiol. 65:1061-1070.

38. Yedidia, I., Benhamou, N., Kapulnik, Y., and Chet, I. 2000. Induction and accumulation of PR proteins activity during early stages of root colonization by the mycoparasite Trichoderma harzianum strain T-203. Plant Physiol. Biochem. 38:863-873.

39. Yedidia, I., Srivastva, A. K., Kapulnik, Y., and Chet, I. 2001. Effect of Trichoderma harzianum on microelement concentrations and increased growth of cucumber plants. Plant Soil 235:235-242.

40. Zhang, J., Howell, C. R., and Starr, J. L. 1996. Suppression of Fusarium colonization of cotton roots and Fusarium wilt by seed treatments with Gliocladium virens and Bacillus subtilis. Biocontrol Sci. Technol. 6:175-187. 